\title{
Paulus dan Perempuan
}

\section{Paul and Woman}

\author{
Randy Frank Rouwl)* Julian Frank Rouw ${ }^{2)}$ \\ 1) Sekolah Tinggi Filsafat Theologia Jaffray Makassar, Sulawesi Selatan \\ 2) Sekolah Tinggi Teologi Kanaan Nusantara Ungaran, Jawa Tengah \\ *)Penulis korespondensi: randyrouw@gmail.com
}

Received: 13 February 2019/Revised: 06 September 2019 /Accepted: 22 September 2019

\begin{abstract}
Abstrak
Artikel ini berfokus untuk menjawab beberapa pertanyaan meliputi: (1) Siapa rekan-rekan perempuan Paulus? (2) Apa ajaran Paulus untuk istri-istri? (3) Apa ajaran Paulus tentang perempuan dan pelayanannya? (4) Menurut Paulus, apakah perempuan dapat melayani sebagai penilik jemaat? (5) Menurut Paulus, apakah perempuan dapat melayani sebagai diaken? (6) Menurut Paulus, apakah ada perbedaan antara pelayanan laki-laki dan pelayanan perempuan? (7) Apa yang ditulis Paulus mengenai pelayanan perempuan? Kesimpulan dari penelitian ini adalah ada perbedaan dalam pelayanan laki-laki dan pelayanan perempuan menurut Paulus. Ekspektasi Paulus, seorang penilik jemaat adalah seorang laki-laki dan bukan perempuan. Namun, perempuan dapat berperan dalam pelayanan diaken. Perempuan juga dapat mendidik perempuan lain yang lebih muda. Berkaitan dengan istri, Paulus menekankan akan ketundukan istri terhadap suami. Bukan bentuk diskriminasi terhadap kaum perempuan. Ini penekanan Paulus bagi istri; istri tunduk kepada suami sebagai wujud perempuan yang takut akan Tuhan. Istri sadar bahwa suami adalah "sumber keberadaan" mereka.
\end{abstract}

Kata-kata Kunci: Paulus, Perempuan, Istri, Tuhan, Kristus

\begin{abstract}
This article focus to answer a couple of question, include: (1) Who are Paul women partners? (2) What is Paul's teaching about wives? (3) What is Paul's teaching about a woman and her ministry? (4) According to Paul, can woman serve as an overseer? (5) Can a woman serve as a deacon? (6) Is there any difference ministry between man and woman? (7) What did Paul write about woman ministry? The conclusion is there are differences between man and woman ministry according to Paul. Paul's expectation tells us that an overseer is a man and not a woman. However, a woman can be a deacon. A woman can teach another woman that younger. About wife, Paul tells us that wife should submit to her husband. About this, not discrimination. Paul's emphasis on wives; the wife should submit to the husband as a form of their fear of God. The wife realizes that her husband is her "existence source."
\end{abstract}

Keywords: Paul, Woman, Wife, God, Christ. 


\section{Pendahuluan}

Memahami pikiran Paulus terkait peranan perempuan dalam pelayanan maupun kehidupan berkeluarga tidaklah mudah. Berbagai pandangan mengenai Paulus dan perempuan menciptakan perdebatan yang masih berlangsung hingga saat ini. Beberapa nas dalam Alkitab yang menunjukkan seperti ada diskriminasi terhadap perempuan memberikan penilaian negatif terhadap Paulus. Efesus 5 dan Kolose 3 menekankan supaya istri tunduk pada suami, l Korintus 14:34-35 tentang perempuan harus diam dalam pertemuan jemaat, dan 1 Timotius 2:11-12 yang adalah larangan untuk perempuan mengajar. Bagi beberapa orang ayat-ayat tersebut dapat menjadi dasar bahwa Paulus adalah seorang yang diskriminatif, dan pembenci perempuan. Penekanannya terhadap perempuan terlalu keras.

Penulis dalam hal ini akan membahas topik mengenai Paulus dan perempuan kaitannya dalam hubungan suami istri dan peran perempuan dalam pelayanan. Penulis mencoba turut terlibat dalam diskusi mengenai topik ini. Melalui 7 pertanyaan yang dipaparkan, harapan penulis hal ini dapat membantu dan menjadi opsi dalam menghadapi perdebatan mengenai topik Paulus dan perempuan.

\section{Metode}

Dalam penelitian ini, penulis menggunakan metode kualitatif. Metode ini ditandai dengan masalah yang tentatif dan berkembang (tidak tetap) serta tidak menggunakan data-data statistika. ${ }^{l}$ Berkaitan dengan itu, pendekatan yang penulis ambil adalah studi kepustakaan. Penulis mencari sumber pendukung penelitian dari sumber-sumber seperti buku-buku berkaitan dengan Paulus, tafsiran dari beberapa kitab maupun jurnal.

\section{Pembahasan}

\section{Rekan-rekan Perempuan Paulus}

Dalam pelayanan, Paulus memiliki rekan-rekan perempuan. Hal ini membuktikan bahwa Paulus bukanlah seorang yang mendiskriminasi perempuan atau pembenci perempuan. Alkitab pun mencatatkan beberapa nama perempuan sebagai rekan-rekan Paulus. Perempuan pertama adalah Lidia. Lidia muncul di dalam Kisah Para Rasul 16:14-15; seorang penjual kain ungu dari Kota Tiatira yang beribadah kepada

${ }^{1}$ Hengki Wijaya, Analisis Data Kualitatif Ilmu Pendidikan Teologi (Makassar: Sekolah Tinggi Theologia Jaffray, 2018), 1-2. 
Allah². Tuhan membuka hati Lidia, Bock mencatatkan saat itu ia menjadi percaya (dibuktikan di ayat 15 di mana Lidia dan seisi rumahnya dibaptis). ${ }^{3}$ Lidia membantu Paulus dan rekan-rekannya; ia menjadikan rumahnya sebagai tempat mereka menetap. Bock mencatatkan rumahnya pada akhirnya menjadi pusat untuk iman yang baru di kota Filipi. ${ }^{4}$

Perempuan kedua adalah Priskila/Priska. ${ }^{5}$ Priskila sudah menikah; suaminya adalah Akwila. Ia beserta suaminya sebelumnya berada di Italia, namun berpindah ke Korintus karena maklumat Klaudius (Kis. 18:2). Mereka adalah rekan sekerja Paulus di dalam Kristus Yesus (Rm. 16:3); mereka sempat menemani Paulus hingga Efesus (Kis. 18:18-19). Ia dan Akwila memiliki pekerjaan yang sama; sebagai tukang kemah (Kis. 18:3). Perempuan ketiga adalah Febe (Rm. 16:1-2). Disebutkan Febe adalah pelayan $^{6}$ di jemaat Kengkrea (ay. 1). Hagelberg menyatakan bahwa kemungkinan Febe adalah perempuan yang kaya dan berpengaruh; ia

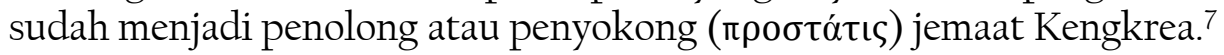

Perempuan keempat adalah Maria (Rm. 16:6). Hagelberg mencatatkan bahwa kemungkinan Maria ini adalah orang Yunani. ${ }^{8}$ Ia adalah seorang perempuan yang telah banyak membantu Paulus dengan

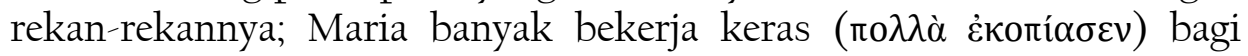
mereka. Perempuan kelima adalah Yunias (Rm. 16:7). Disebutkan bahwa

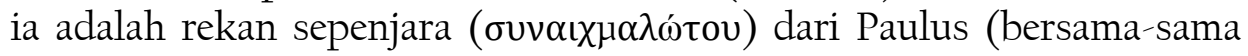
Andronikus) $)^{9}$ dan lebih dahulu percaya kepada Kristus daripada Paulus. Ia serta Andronikus Paulus sebut sebagai orang-orang yang terkemuka $(\dot{\varepsilon} \pi i ́ \sigma \eta \mu o \iota)^{10}$ di antara para rasul ${ }^{11}$. Perempuan keenam dan ketujuh adalah

2 Bock menjelaskan frasa "beribadah kepada Allah" sering mendeskripsikan seorang politeisme yang menjadi penyembah Allah Israel, datang ke sinagoge namun tidak memegang seluruh hukum. Frasa ini menunjukkan bahwa Lidia adalah orang yang saleh. Darrell L. Bock, Baker Exegetical Commentary on the New Testament: Acts (Grand Rapids, Michigan: Baker Academic, 2007), 534.

${ }^{3}$ Ibid.

${ }^{4}$ Ibid., 534-535.

${ }^{5}$ Rekan perempuan Paulus yang namanya paling sering muncul dalam Alkitab (Kis. 18:2, 18-20, 26; Rm. 16:3; 1 Kor. 16:19; 2 Tim. 4:19).

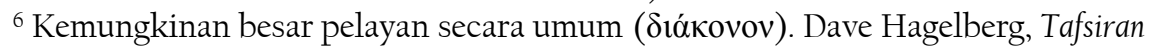
Roma Dari Bahasa Yunani (Bandung: Kalam Hidup, 2013), 339.

${ }^{7}$ Ibid.

${ }^{8}$ Ibid., 342. istri. Ibid.

${ }^{9}$ Dave Hagelberg berpendapat bahwa Andronikus dan Yunias adalah suami dan

${ }^{10}$ Hagelberg menilai Yunias dan Andronikus adalah orang yang dikenal baik di kalangan rasul. Hagelberg, Tafsiran Roma Dari Bahasa Yunani, 342. Powers menilai bahwa mereka orang yang memang terkenal dan ada kemungkinan bahwa mereka adalah seorang rasul juga. Ward Powers, The Ministry of Women in the Church: Which Way Forward? (Australia: SPCK, 1996), 141-145. 
Trifena dan Trifosa (Rm. 16:12). Hagelberg mencatatkan kemungkinan

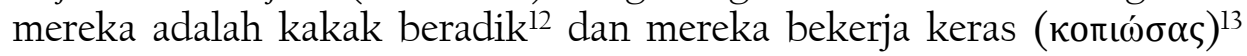
untuk Tuhan. Perempuan kedelapan adalah Persis (Rm. 16:12). ${ }^{14}$ Paulus menyebutnya "yang kukasihi". ${ }^{5}$ Persis juga disebutkan Paulus sebagai orang yang telah bekerja keras dalam Tuhan. ${ }^{16}$ Perempuan kesembilan adalah Yulia (Rm. 16:15). Tidak terlalu jelas keberadaan Yulia. Pastinya ia adalah kenalan Paulus dan orang yang cukup penting sampai-sampai Paulus menyebutkannya dalam salamnya. Hagelberg menyebutkan bahwa ia bukan seorang budak karena namanya adalah nama asli Roma. ${ }^{17}$ Perempuan kesembilan dan kesepuluh adalah Euodia dan Sentikhe (Flp. 4:2). Mereka berdua adalah rekan pelayanan Paulus; sama-sama berjuang dalam pekabaran Injil (Flp. 4:3). Meyers mengemukakan bahwa mereka adalah orang penting bagi terbentuknya gereja di Filipi. ${ }^{18}$ Perempuan kesebelas adalah Nimfa (Kol. 4:15). Sebenarnya tidak diketahui pasti apa kelamin dari Nimfa (Nv́ $\mu \varphi \alpha v),{ }^{19}$ namun jika benar ia adalah perempuan, ia perempuan yang penting. Dalam salam Paulus, sepertinya Nimfa menyediakan rumahnya sebagai tempat untuk pertemuan atau ibadah jemaat. Perempuan keduabelas adalah Apfia (Flm. 2). Paulus menyebutnya sebagai saudara perempuan. Meyers menerima perspektif bahwa ia adalah salah seorang pelayan di jemaat saat itu; juga rekan pelayanan Filemon dan Arkhipus. ${ }^{20}$

\section{Ajaran Paulus untuk Istri-istri}

Dalam Surat Efesus dan Surat Kolose, pengajaran yang diulang oleh Paulus adalah istri haruslah tunduk terhadap suaminya (Ef. 5:22; Kol. 3:18). Kata "tunduk" berasal dari kata hupotassesthe (vंпот́́ $\sigma \sigma \varepsilon \sigma \theta \varepsilon$ ) yang berarti "menjadi tunduk/takluk". Dalam Surat Kolose, selain istri harus

\footnotetext{
${ }^{11}$ Mereka adalah rasul-rasul jemaat seperti yang disebut dalam 2 Korintus 8:23. Hagelberg, 342.

12 Ibid., 345.

${ }^{13}$ Hagelberg menyebutkan bahwa pemakaian present participle memberi kesan mereka "selalu bekerja keras". Hagelberg, 345.

${ }^{14}$ Kemungkinan ia adalah mantan budak. Ibid., 345-46.

${ }^{15}$ Carol Meyers menyebutkan ini merupakan bentuk penghargaan orang Kristen Roma kepadanya. Carol Meyers, Women in Scripture (New York: Houghton Mifflin Company, 2000), s.v. "Persis".

${ }^{16}$ Menurut Meyers ia adalah orang yang cukup penting dalam terbentuknya gereja di Roma. Ibid.

${ }^{17}$ Hagelberg, Tafsiran Roma Dari Bahasa Yunani, 346.

${ }^{18}$ Meyers, Women in Scripture, s.v. "Euodia".

19 Ada perdebatan mengenai apakah Nimfa laki-laki atau perempuan. Dave Hagelberg, Tafsiran Surat Kolose dari Bahasa Yunani, trans. oleh Yohanes Effendi (Yogyakarta: ANDI, 2013), 266-67.

${ }^{20}$ Meyers, Women in Scripture.
} 
tunduk, Paulus menekankan bahwa sikap tunduk itu "sebagaimana seharusnya di dalam Tuhan." Selain menjadi kesaksian dan memberi kesan baik kepada orang-orang kafir, ${ }^{21}$ ketundukan dan ketaatan istri kepada suami adalah bukti sebagai istri yang takut akan Tuhan. Sebagai penjelasan, Hagelberg mengungkapkan, “... karena kita telah diubah menjadi umat manusia baru yang kepalanya adalah Tuhan Yesus, sepatutnya istri-istri tunduk kepada suami mereka."22 Istri yang hidup dalam Tuhan, yang memiliki kepala dan teladan sejati yaitu Yesus Kristus, ia harus menjadi istri yang tunduk kepada suami.

Kemudian penjelasan yang lengkap dapat diperoleh dalam Surat Efesus. Dalam surat ini, sebenarnya kata hupotassesthe/hopotasso dipakai di dalam ayat 21, bukan 22 - berkaitan dengan merendahkan diri dalam takut akan Kristus. ${ }^{23}$ O'Brien menjelaskan bahwa gagasan mengenai "tunduk" di dalam ayat 21 dijelaskan tanpa perlu pengulangan verba di ayat 22. ${ }^{24}$ Melanjutkan pembahasannya, O'Brien mencatat demikian, "Seperti yang telah kita lihat, kata kunci yang diterjemahkan "tunduk" harus terkait erat dengan sikap merendah seseorang dalam suatu urutan kepangkatan kepada yang lain yang berada di atas, yaitu dalam otoritas atas seseorang. Inti dari sikap tunduk adalah gagasan "urutan." 25 Istri yang tunduk berarti adalah istri yang bersikap merendahkan diri terhadap suaminya. Ia sadar akan "urutannya" sebagai seorang istri. Hagelberg menilai hal ini juga menjadi awasan bagi istri supaya mampu melawan godaan untuk memerintah suaminya. ${ }^{26}$

Dalam Surat Efesus ketundukan istri kepada suami adalah "seperti kepada Tuhan". Brauch menegaskan sikap tunduk istri kepada suami ada dalam kebebasan; kebebasan orang yang mengikuti jejak Tuhan. ${ }^{27}$

Brauch menyatakan sikap seperti ini adalah tantangan..$^{28}$ Oleh karena itu, Paulus melanjutkan pembahasannya dengan menyebutkan

${ }^{21}$ Dalam buku ini dituliskan bahwa tujuan penulis Kolose dalam topik ini adalah mendorong agar jemaat memberi kesan yang baik terhadap para tetangga mereka yang kafir sehingga tidak ada halangan dalam pewartaan Injil. Pengarang menasihati jemaat untuk mengikuti peraturan-peraturan yang berlaku di masyarakat yang berkaitan dengan hubungan keluarga, yang mana adalah sebuah kewajiban bagi istri untuk taat kepada suaminya dalam budaya patriarkat. Dianne Bergant dan Robert J. Karris, ed., Tafsir Alkitab Perjanjian Baru (Yogyakarta: Kanisius, 2002).

22 Hagelberg, Tafsiran Surat Kolose dari Bahasa Yunani, 230.

23 Secara struktur penulisan sebenarnya penerjemahan menggunakan kata "tunduk" tidak tepat. Tidak ada kata tunduk di dalam bahasa aslinya. Manfred T. Brauch, Ucapan Paulus Yang Sulit (Malang: Literatur SAAT, 2012), 226.

${ }^{24}$ Peter T. O’Brien, Surat Efesus (Surabaya: Momentum, 2013), 502.

25 Ibid.

${ }^{26}$ Hagelberg, Tafsiran Surat Kolose dari Bahasa Yunani, 229.

27 Brauch, Ucapan Paulus Yang Sulit, 227.

${ }^{28}$ Ibid. 
bahwa laki-laki adalah "kepala" sama seperti Kristus yang adalah kepala

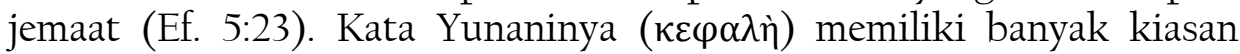
salah satunya yang Brauch pakai untuk menjelaskan adalah "sumber". Brauch kembali menjelaskan, “... menurut rancangan Allah, laki-laki merupakan sumber keberadaan perempuan; mereka diciptakan seorang untuk yang lainnya dan merupakan satu kesatuan." ${ }^{29}$ Istri tunduk bukan karena rasa takut akan kekuasaan; ia tunduk dikarenakan sadar bahwa sumber keberadaannya adalah karena suami; seperti Kristus juga sumber keselamatan gereja melalui pengorbanan-Nya. Seperti yang Jacobs tuliskan bahwa fokusnya adalah Kristus. ${ }^{30}$ Hubungan ini bukan lagi diungkapkan dengan kata "kekuasaan" namun "bahasa sumber", ungkap Brauch. ${ }^{31}$ Memang sikap tunduk ini adalah sebuah kebebasan, namun tidak terlepas dari kesadaran sang istri bahwa suami menjadi sumber keberadaannya; seperti Yesus adalah sumber keberadaan - Juruselamat jemaat.

Demikianlah ajaran Paulus yang terutama bagi istri. Mereka harus tunduk kepada suami. Sebagai perempuan yang ada di dalam Tuhan setiap istri harus tunduk kepada suaminya. Sikap tunduk dalam bentuk siap merendahkan diri dan sadar bahwa laki-laki adalah kepala mereka; sebagai sumber keberadaan mereka. Hal ini berarti secara tidak langsung menunjukkan tidak adanya diskriminasi antara laki-laki dengan perempuan.

Alasan yang pertama, sikap tunduk ini ada di dalam konteks hubungan suami dengan istri. Paulus tidak menganjurkan bahkan membenarkan bahwa para perempuan harus tunduk kepada para pria, seperti yang diungkapkan oleh O'Brien. ${ }^{32}$ Fokus Paulus dalam hal ini adalah sikap istri kepada kepala keluarga, yaitu suami. Ia harus bersikap tunduk; merendahkan dirinya dengan sukarela, karena - kembali lagi ia sadar akan posisinya sebagai istri; ia sadar suami sebagai sumber keberadaannya. Kedua, diskriminasi terhadap perempuan telah dihapuskan. Hekh ten Napel menuliskan bahwa hal ini didasari oleh Galatia 3:28 bahwa laki-laki dan perempuan dinyatakan sama nilainya di hadapan Allah, dan sikap merendahkan perempuan itu dihapuskan. ${ }^{33}$

${ }^{29}$ Brauch., 228.

30 Jacobs menggunakan istilah "motivasi kristologi". Tom Jacobs, Paulus: Hidup, Karya dan Teologinya (Yogyakarta: Kanisius, 1983), 370.

${ }^{31}$ Brauch, Ucapan Paulus Yang Sulit, 227.

32 O'Brien dengan tegas mengatakan bahwa Paulus tidak menasihati setiap perempuan untuk tunduk kepada pria, namun para istri harus tunduk kepada suamisuaminya. O'Brien, Surat Efesus, 502.

${ }^{33}$ Henk ten Napel, Jalan Yang Lebih Utama Lagi: Etika Perjanjian Baru (Jakarta: BPK Gunung Mulia, 1990), 138. 
Perbedaan telah dihapuskan di dalam Kristus; perempuan dan pria punya nilai yang sama di dalam Allah. Meski demikian memang ada perintah bagi istri untuk tunduk kepada suaminya. Bukan bentuk diskriminasi, namun inilah "bentuk sikap merendahkan diri yang meneladani Yesus"34 dan juga sebagai wujud hubungan antara Kristus (suami) dan jemaat (istri). Pemikiran yang harus dibangun adalah tunduknya istri kepada suami bukanlah diskriminasi - itu merupakan bentuk keteladanan kepada Yesus yang juga rela merendahkan diri-Nya. Brauch mencatatkan bahwa ini adalah sikap murid Tuhan yang mengikuti jejak Yesus sebagai hamba. ${ }^{35}$ Lagipula - mengulangi penyataan Brauch - sikap ini adalah sikap sukarela, ada kebebasan, berkaitan dengan kesadaran akan suami sebagai sumber keberadaan istri, bukan lagi berkaitan dengan kekuasaan. ${ }^{36}$

Demikian, penekanan Paulus kepada istri adalah untuk tunduk kepada suaminya. Ini bukanlah diskriminasi. Ini merupakan wujud meneladani sikap Kristus yang juga mau merendahkan diri-Nya. Istri tunduk berarti ia mau merendahkan diri kepada suaminya, dan menghormati suaminya. Menghormati suami adalah lebih penting daripada sekadar "tunduk".

\section{Perempuan dan Pelayanan}

Sebelum menjawab pertanyaan-pertanyaan penting mengenai pelayanan perempuan, penulis hendak membahas beberapa nas dari surat-surat Paulus yang berkaitan dengan perempuan. Pertama, 1 Korintus 14:34-35. Terdapat perintah dari Paulus kepada perempuan untuk berdiam diri dalam pertemuan ibadah. Mereka tidak diperbolehkan berbicara dan harus tunduk (ay. 34). Jika perempuan ingin mengetahui sesuatu, mereka harus bertanya kepada suaminya di rumah (ay. 35). Sependapat dengan penyataan Brauch, pernyataan Paulus ini berkaitan dengan ibadah. Dalam konteks ini ada masalah dalam ibadah jemaat. ${ }^{37}$ Salah satu yang Paulus soroti adalah sikap perempuan dalam ibadah. Penulis sependapat dengan yang disampaikan Powers bahwa ini bukan pelarangan secara universal kepada perempuan; semua perempuan dilarang berkhotbah atau mengajar. ${ }^{38}$ Alejandrino juga mengungkapkan hal yang demikian. Tulisan ini dikhususkan bagi istriistri Kristen, bukan kepada semua perempuan. ${ }^{39}$ Ini tidak cocok dengan konteksnya. Powers mencatatkan bahwa kata yang dipergunakan untuk

\footnotetext{
${ }^{34}$ Brauch, Ucapan Paulus Yang Sulit, 227.

35 Ibid., 138.

${ }^{36}$ Ibid., 227-28.

37 Brauch, 227.

${ }^{38}$ Powers, The Ministry of Women in the Church: Which Way Forward?, 62.

${ }^{39}$ Miriam R. Alejandrino, "Paul: A Misogynist," Landas 28, no. 2 (2014):122.
} 
perempuan berbicara adalah laleo $(\lambda \alpha \lambda \dot{\varepsilon} \omega)$, yang sebenarnya tidak berkaitan dengan mengajar atau berkhotbah. ${ }^{40}$ Ini berkaitan dengan pembicaraan kecil, perbincangan informal, bercakap-cakap, mengobrol atau mengoceh. ${ }^{41}$ Paulus sepertinya melihat ada sikap (beberapa) istri yang mengganggu pertemuan jemaat. Beberapa di antara mereka mungkin sering bercakap-cakap, dan mengobrol ketika ibadah. ${ }^{42}$ Sepertinya istri memiliki rasa ingin tahu yang besar ketika beribadah sehingga Paulus memerintahkan mereka untuk berdiam diri dalam ibadah. Mereka harus bertanya kepada suami mereka jika ingin mengetahui sesuatu. Alejandrino mengungkapkan bahwa ini adalah sikap yang pantas/sopan bagi seorang istri. ${ }^{43}$ Fokusnya adalah supaya ibadah teratur dan sopan (1 Kor. 14:33b, 40).

Kedua, 1 Timotius 2:11-12. Paulus memerintahkan perempuan untuk berdiam dan menerima ajaran dengan patuh (ay. 11). Ia melanjutkan lagi melarang perempuan untuk mengajar dan tidak mengizinkan perempuan untuk memerintah laki-laki (ay. 12). Menurut Ward Powers, perintah di dalam bagian ini berkaitan dengan hubungan suami istri. ${ }^{44}$ Paulus sedang mengomentari hubungan suami dan istri di dalam keluarga. Seorang istri tidak boleh mengajar ataupun memerintah suami, ia harus tunduk pada suami. Peran istri bukanlah memerintah suami; itu adalah otoritas dari seorang suami. ${ }^{45}$ Namun menurut penulis, konteks ini berbeda. Paulus bukan berfokus pada hubungan suami istri. Brauch memiliki pandangan yang berbeda. Jemaat sepertinya sedang dipengaruhi oleh pengajaran-pengajaran sesat, salah satu yang terpengaruhi adalah kaum perempuan. Perempuan "telah menjadi para pendukung yang sangat kuat dari gagasan-gagasan yang mengacaukan situasi kehidupan jemaat dan rumah tangga yang sudah tertata.“46

Brauch melanjutkan, ketaatan dalam bagian ini kemungkinan besar adalah ketaatan kepada tua-tua dalam jemaat yang merupakan penjaga kebenaran dan ibadah yang teratur. Perempuan dilarang

${ }^{40}$ Powers, The Ministry of Women in the Church: Which Way Forward?, 62.

${ }^{41}$ Ibid., 62.

${ }^{42}$ Garland mengungkapkan bahwa ini bukan kata-kata ocehan atau celotehan yang tidak penting. Laleo tidak menggambarkan percakapan yang seperti itu, malah sebaliknya, laleo adalah bercakap-cakap dengan pikiran atau menggunakan akal dalam berbicara. Garland melanjutkan lagi jika memang yang dimaksudkan Paulus adalah pembicaraan yang tidak penting pasti Paulus meggunakan kata kenophonia (kata kosong) atau mataiologia (omong kosong, perkataan yang tidak bermanfaat). David E. Garland, Baker Exegetical Commentary on the New Testament: 1 Corinthians (Grand Rapids, Michigan: Baker Academic, 2008).

${ }^{43}$ Miriam R. Alejandrino, "Paul: A Misogynist," Landas 28, no. 2 (2014):123.

${ }^{44}$ Powers, The Ministry of Women in the Church: Which Way Forward?, 52.

45 Ibid.

${ }^{46}$ Brauch, Ucapan Paulus Yang Sulit, 271. 
mengajar dilarang untuk mengajar disebabkan ada keterlibatan (beberapa perempuan) dalam pengajaran palsu. ${ }^{47}$ Menurut Brauch, perempuan dilarang untuk memerintah laki-laki harus dimengerti dalam konteks penolakan terhadap kekuasaan orang lain, barangkali pemimpin di Efesus. ${ }^{48}$ Akhirnya Brauch menjelaskan bahwa memang ada pembatasan bagi perempuan dalam kehidupan dan pelayanan dalam jemaat Efesus dan ini ditujukan kepada para perempuan yang terlibat dalam pengajaran palsu (yang menolak untuk diajar dan mau mendominasi kekuasaan dalam jemaat). ${ }^{49}$ Namun, berkaitan dengan pandangan Brauch, bagi penulis, Saat itu tidak ada indikasi Paulus berbicara mengenai ajaran sesat yang memengaruhi perempuan-perempuan. Menurut penulis, ini memang larangan Paulus bagi perempuan. Bagi Paulus, perempuan tidak diizinkan untuk mengajar dan memerintah laki-laki. Hal ini berkaitan dengan pelayanan penilik jemaat dalam pasal selanjutnya (1 Tim. 3:1-7).

Berdasarkan pembahasan singkat dari kedua bagian dari surat Paulus, terdapat larangan dari Paulus untuk perempuan. 1 Korintus 14:34-35 tidak berisi larangan perempuan untuk melayani. 1 Timotius 2:11-12 yang menjadi dasar perempuan tidak diizinkan untuk mengajar dan memerintah laki-laki dan ini berkaitan dengan pelayanan sebagai penilik jemaat.

Menurut surat Paulus, apakah perempuan dapat melayani sebagai penilik jemaat? Dalam surat pastoral berkaitan dengan kualifikasi seorang penilik jemaat, tidak ada indikasi perempuan terlibat dalam pelayanan ini atau penyampaian langsung bahwa Paulus sendiri mengizinkan perempuan terlibat dalam pelayanan ini. Sepertinya Paulus punya ekspektasi bahwa penilik jemaat adalah seorang laki-laki nantinya. Hal ini dilihat dari sebuah persyaratan yang Paulus beri, yaitu "suami dari satu istri." Ini mengindikasikan bahwa Paulus punya pikiran bahwa seorang penilik pasti seorang laki-laki. Jika memang perempuan juga terlibat, ia bisa memberikan persyaratan "atau perempuan dari satu suami", namun hal itu tidak ada. Meskipun seperti diungkapkan beberapa penafsir bahwa persyaratan tersebut berfokus terhadap kesetiaan suami di dalam keluarga ${ }^{50}$ bukan mengenai persyaratan jenis kelamin seorang penilik, kita dapat melihat ekspektasi Paulus mengenai seorang penilik jemaat; ia adalah seorang laki-laki. Mengacu kepada 1 Timotius 2:11-12 terdapat

${ }^{47}$ Brauch, 271.
${ }^{48}$ Ibid.
${ }^{49}$ Brauch mengutip David M. Scholer, Women, Authority $\mathrm{w}$ the Bible, 205. Ibid.
${ }^{50}$ Gordon D. Fee, New International Biblical Commentary: 1 and 2 Timothy, Titus (U.S.A.: Hendrickson Publishers and Paternoster Press, 1988), 80-81, George W. Knight III, The Pastoral Epistles: A Commentary on the Greek Text (Grand Rapids, Michigan: Williams B. Eerdmans Publishing Company, 1999), 157-59. 
larangan bagi perempuan untuk mengajar dan menurut penulis ini berkaitan dengan persyaratan penilik jemaat dalam pasal 3; ada larangan bagi perempuan untuk menjadi penilik jemaat. Selain itu, Paulus memiliki rekan-rekan perempuan yang juga melayani, namun tidak ada dicatatkan bahwa ada seorang rekan perempuannya yang terlibat dalam pelayanan sebagai penilik jemaat. Meskipun Powers menilai bahwa Yunias (Rm. 16:7) bisa jadi adalah seorang penilik jemaat/penatua pertama, ${ }^{51}$ namun itu tidak jelas. Sebagai kesimpulan, menurut penulis, jika didasarkan pada ekspektasi dari Paulus mengenai seorang penilik jemaat, Paulus sepertinya tidak mengizinkan perempuan untuk melayani sebagai penilik jemaat.

Menurut surat Paulus, apakah perempuan dapat melayani sebagai diaken? Sama seperti seorang penilik jemaat, Paulus tidak memberikan kriteria jenis kelamin seorang diaken. Namun, menurut penulis seorang perempuan dapat terlibat menjadi seorang diaken. Memang Paulus memberikan persyaratan bahwa diaken haruslah "suami dari satu istri" (1 Tim. 3:12), dan ini juga jadi ekspektasi Paulus terhadap seorang diaken, bahwa ia juga merupakan seorang laki-laki, yang setia dalam keluarga. Namun lanjut dalam persyaratan-persyaratan yang dikemukakan Paulus mengenai diaken, ia berbicara juga mengenai syarat bagi "istri-istri" (ay. 11). Kata yang dipergunakan adalah gunaikas yang dapat diartikan "istri" atau "perempuan" ${ }^{52}$ Knight memberikan beberapa kemungkinan yang dimaksud dengan "istri-istri" di sini: (1) perempuan yang adalah bagian dari diaken, (2) mereka adalah diaken perempuan tetapi sebanding dengan diaken laki-laki, (3) mereka adalah asisten perempuan diaken, dan (4) mereka adalah istri-istri diaken. ${ }^{53}$ Knight memperkirakan kemungkinan yang mendekati adalah poin ke-3 atau ke4.54

Powers punya pandangan yang cukup berbeda. Menurutnya, Paulus bukan bermaksud persyaratan tersebut bagi istri dari diaken.55 Ada 4 alasan yang Powers berikan. Pertama, jika memang yang dimaksud adalah istri diaken, maka seharusnya menggunakan kata "istri mereka" bukan hanya "istri-istri". Paulus mengawali persyaratan ini dengan tujuan kepada hanya "perempuan-perempuan" atau "istri-istri", bukan spesifik kepada "istri mereka". Kedua, jika memang ini ditujukan bagi istri diaken, seharusnya penempatan persyaratan ini ada sesudah persyaratan mengenai "mengurus anak-anak dengan baik" (ay. 12) bukan

\footnotetext{
${ }^{51}$ Powers, The Ministry of Women in the Church: Which Way Forward?, 141-47.

52 Bibleworks 8, "Гvvaĩкas."

${ }^{53}$ Knight III, The Pastoral Epistles: A Commentary on the Greek Text, 170-71.

${ }^{54}$ Ibid., 171.

55 Powers, The Ministry of Women in the Church: Which Way Forward?, 159.
} 
sebelum persyaratan ini, karena seorang istri juga punya peran penting dalam mengurus anak. Ketiga, persyaratan mengenai tersebut diawali

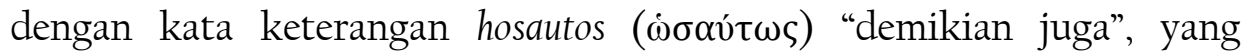
merupakan pengulanagn dari ayat 8 dan ini juga yang dipakai untuk memperkenalkan 3 kelompok pelayan gereja (penilik, penatua dan diaken). Istri diaken pastinya tidak memenuhi ekspektasi dari kata "demikian juga" yang sebenarnya hanya dikategorikan kepada 3 kelompok besar pelayan gereja. Keempat, kualifikasi ini hanya ada di antara pembahasan mengenai persyaratan diaken, tidak ada pararelnya di dalam 1 Timotius 3:1-7 dan Titus 1:5-9. Jika memang yang dimaksudkan adalah istri diaken, maka istri seorang penilik dan penatua juga harus memiliki persyaratan juga, tidak hanya seorang istri seorang diaken. Demikian pandangan Powers di mana Paulus bukan memaksudkan persyaratan ini kepada istri dari seorang diaken.

Apa yang Paulus tuliskan bukannya ditujukan bagi istri diaken. Ada kemungkinan ditujukan kepada perempuan yang melayani sebagai diaken juga atau seperti yang Knight sampaikan, ada seorang asisten perempuan seorang diaken. Hal ini menjadi bukti bahwa dahulu perempuan sudah terlibat dalam pelayanan sebagai diaken atau asistennya. Selain itu, Paulus juga memiliki rekan-rekan perempuan yang terlibat sebagai diaken juga. Ini menjadi dasar saya menyetujui bahwa seorang perempuan bisa melayani sebagai seorang diaken.

Apakah perempuan dapat berkhotbah? Orang menentang seorang perempuan berkhotbah seringkali didasarkan pada 1 Timotius 2:11-12, yang mana Paulus memerintahkan perempuan untuk berdiam diri serta melarang perempuan untuk mengajar. Seperti yang sudah penulis bahas dalam pembahasan sebelumnya, jika melihat konteks dari ayat ini larangan ini berkaitan dengan pelayanan perempuan sebagai penilik jemaat. Terdapat larangan terhadap perempuan untuk menjadi seorang penilik jemaat, namun tidak ada larangan perempuan untuk berkhotbah. Ayat ini tidak membuktikan bahwa perempuan saat ini tidak berkhotbah. Surat Paulus tidak melarang perempuan untuk mengajar atau berkhotbah. Saat ini pun perempuan punya kesempatan yang sama seperti laki-laki; perempuan dapat mengajar atau berkhotbah.

Adakah perbedaan di antara pelayanan laki-laki dan pelayanan perempuan? Dalam pelayanan sebagai pemimpin gereja, perempuan seperti dibatasi untuk tidak melayani sebagai penilik, namun mereka dapat melayani sebagai diaken. Ridderbos menyatakan, "Di satu pihak, perempuan berbagian penuh dalam keselamatan di dalam Kristus, dan terdapat kesetaraan penuh antara laki-laki dan perempuan dalam hal itu

Di lain pihak, persekutuan dalam Kristus tidak melenyapkan perbedaan alamiah antara laki-laki dan perempuan dan posisi 
kepemimpinan laki-laki atas perempuan." ${ }^{56}$ Sepertinya ada perbedaan pelayanan antara laki-laki dan perempuan dari sudut pandang Paulus. Kemudian, apakah yang ditulis Paulus mengenai pelayanan perempuan? Perempuan dapat melayani sebagai seorang diaken. Kemudian, dalam 1 Korintus 11:5, perempuan dapat berdoa dan bernubuat. Kemudian di dalam Titus 2:3-4 tertulis juga bentuk pelayanan yang lain bagi perempuan, secara khusus "perempuan-perempuan tua". Dalam ayat 3 Paulus memberikan kriteria kepada perempuan yang tua. Mulai dari orang-orang yang beribadah ${ }^{57}$, jangan memfitnah, jangan menjadi hamba anggur, yang juga cakap mengajarkan hal-hal baik. Melalui kehidupannya - ini menjadi pelayanannya - dapat mendidik perempuan-perempuan yang lebih muda. Dapat dilihat bahwa perempuan juga punya peran dalam mengajar, mendidik yang lebih muda. House mengungkapkan bahwa seorang perempuan yang takut akan Tuhan punya peran juga dalam mengajar; perempuan tidak dinilai mencerminkan kehidupan Kristen dan bukan kalangan kedua dalam masyarakat. Seorang perempuan yang diberikan karunia mengajar berkesempatan untuk mengajar perempuan lain dalam kelompok kecil atau kelompok besar. Ia dapat melatih perempuan lain untuk melakukan hal yang sama seperti yang dirinya lakukan. ${ }^{58}$ Demikian, ada perbedaan antara laki-laki dan perempuan dalam pelayanan, namun perempuan juga punya bagian dan peran yang penting dalam pelayanan.

\section{Implikasi Praktis}

Implikasi pertama berkaitan dengan pelayanan penilik jemaat. Penulis cukup berhati-hati dalam memberikan implikasi mengenai topik ini. Tidak sedikit saat ini kaum peempuan yang saat ini terlibat dalam pelayanan di gereja, bahkan tidak sedikit juga yang menyerahkan diri dan merasa dipanggil untuk menjadi penilik jemaat atau gembala. Kaitannya dengan hal ini, penulis tidak melarang, mempersalahkan para gembala perempuan atau yang hendak menjadi gembala perempuan. Penulis hendak membawa para pembaca untuk kembali melihat ekspektasi Paulus mengenai seorang penilik jemaat. Penekanan penulis saat ini adalah kepada laki-laki. Penilik jemaat seharusnya adalah laki-

\footnotetext{
${ }^{56}$ Herman Ridderbos, Paulus: Pemikiran Utama Theologinya (Surabaya: Momentum, 2010), 488.

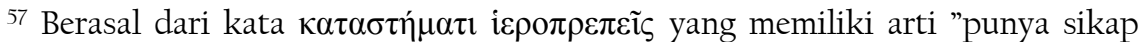
terhormat" atau "memiliki kebiasaan yang pantas dihormati" dan ini juga berkaitan dengan "suci/kudus". Jadi seorang perempuan yang tua harus juga memiliki kehidupan yang patut dihormati orang lain, dan ini juga berkaitan dengan menjaga kekudusan

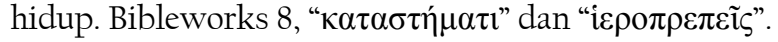

${ }^{58}$ H. Wayne House dalam John Piper dan Wayne Grudem, ed., Recovering Biblical Manhood e Womanhood (Wheaton, Illinois: Crossway Books, 2006).
} 
laki. Tanggung jawab penilik jemaat pada dasarnya harus dipegang oleh laki-laki. Baik perempuan maupun laki-laki harus sadar akan hal ini. Dengan kesadaran ini, laki-laki tidak dengan sembarang memberikan tanggung jawab ini kepada perempuan karena kesadaran akan tanggung jawabnya. Sebaliknya, perempuan dapat "menahan diri" untuk menjadi penilik jemaat atau gembala. Bukan mendiskriminasi peran perempuan karena sebenarnya "perempuan dalam ibadat pada masa kini memegang peranan penting sebagai pelayan Tuhan." 59 Perempuan juga berperan penting dalam gereja. Pelayanan seperti diaken, berkhotbah dan mengajar dapat dilakukan namun memberikan kesempatan lebih besar kepada laki-laki untuk mengemban tanggung jawab penilik jemaat.

Implikasi kedua adalah meskipun ada perbedaan dalam tanggung jawab, tidak ada perbedaan derajat antara perempuan dan laki-laki. Di dalam Kristus, laki-laki dan perempuan sama. Meski demikian dalam hubungan suami dan istri, istri tetap harus memiliki sikap tunduk terhadap suaminya. Ini merupakan sikap yang menunjukkan karakter merendahkan diri layaknya Kristus. Tunduknya istri kepada suami juga menggambarkan hubungan antara Kristus dengan jemaat.

\section{Kesimpulan}

Meski derajatnya tidak ada perbedaan, bagi Paulus terdapat perbedaan antara pelayanan laki-laki dan pelayanan perempuan. Terdapat larangan untuk perempuan menjadi penilik jemaat, namun perempuan dapat terlibat sebagai diaken. Berangkat dari hal tersebut pihak laki-laki harusnya sadar akan tanggung jawab dasarnya sebagai seorang gembala. Demikian juga perempuan memahami dan memberikan kesempatan lebih bagi pria untuk memimpin mendahului bebannya atau rasa ingin untuk memimpin atau menjadi gembala. Paulus juga mengatakan bahwa perempuan dapat mendidik perempuan lain yang lebih muda. Bagi istri, ketundukan kepada suami adalah usaha meneladani sikap sebagai murid Yesus Kristus.

\section{Kepustakaan}

Alejandrino, Miriam R. “Paul: A Misogynist.” Landas 28, no. 2 (2014):11541.

Bergant, Dianne, dan Robert J. Karris, ed. Tafsir Alkitab Perjanjian Baru. Yogyakarta: Kanisius, 2002.

${ }^{59}$ Maria Shintia Kapojos, Randy Frank Rouw, dan Hengki Wijaya, "Implikasi Konteks Perempuan Yahudi dalam Penerapan Gereja Masa Kini," Evangelikal: Jurnal Teologi Injili dan Pembinaan Warga Jemaat 3, no. 2 (31 Juli 2019): 142, diakses 1 Agustus 2019, https://journal.sttsimpson.ac.id/index.php/EJTI/article/view/142/pdf. 
Bock, Darrell L. Baker Exegetical Commentary on the New Testament: Acts. Grand Rapids, Michigan: Baker Academic, 2007.

Brauch, Manfred T. Ucapan Paulus Yang Sulit. Malang: Literatur SAAT, 2012.

Fee, Gordon D. New International Biblical Commentary: 1 and 2 Timothy, Titus. USA.: Hendrickson Publishers and Paternoster Press, 1988.

Garland, David E. Baker Exegetical Commentary on the New Testament: 1 Corinthians. Grand Rapids, Michigan: Baker Academic, 2008.

Hagelberg, Dave. Tafsiran Roma Dari Bahasa Yunani. Bandung: Kalam Hidup, 2013.

. Tafsiran Surat Kolose dari Bahasa Yunani. Diterjemahkan oleh Yohanes Effendi. Yogyakarta: ANDI, 2013.

Jacobs, Tom. Paulus: Hidup, Karya dan Teologinya. Yogyakarta: Kanisius, 1983.

Kapojos, Maria Shintia, Randy Frank Rouw, dan Hengki Wijaya.

"Implikasi Konteks Perempuan Yahudi dalam Penerapan Gereja

Masa Kini." Evangelikal: Jurnal Teologi Injili dan Pembinaan Warga Jemaat 3, no. 2 (31 Juli 2019): 136-43. Diakses 1 Agustus 2019.

https://journal.sttsimpson.ac.id/index.php/EJTI/article/view/142/p df.

Knight III, George W. The Pastoral Epistles: A Commentary on the Greek Text. Grand Rapids, Michigan: Williams B. Eerdmans Publishing Company, 1999.

Meyers, Carol. Women in Scripture. New York: Houghton Mifflin Company, 2000.

Napel, Henk ten. Jalan Yang Lebih Utama Lagi: Etika Perjanjian Baru. Jakarta: BPK Gunung Mulia, 1990.

O'Brien, Peter T. Surat Efesus. Surabaya: Momentum, 2013.

Piper, John, dan Wayne Grudem, ed. Recovering Biblical Manhood e Womanhood. Wheaton, Illinois: Crossway Books, 2006.

Powers, Ward. The Ministry of Women in the Church: Which Way Forward? Australia: SPCK, 1996.

Ridderbos, Herman. Paulus: Pemikiran Utama Theologinya. Surabaya: Momentum, 2010.

Wijaya, Hengki. Analisis Data Kualitatif Ilmu Pendidikan Teologi. Makassar: Sekolah Tinggi Theologia Jaffray, 2018. 